\title{
Spatial variations at different observational scales and the seasonal distributions of stream macroalgae in a Brazilian subtropical region
}

\author{
ROGÉRIO ANTONIO KRUPEK ${ }^{1,4}$, CIRO CESAR ZANINI BRANCO ${ }^{2}$ and \\ CLETO KAVESKI PERES ${ }^{3}$
}

(received: August 31, 2011; accepted: June 01, 2012)

\begin{abstract}
Spatial variations at different observational scales and the seasonal distributions of stream macroalgae in a Brazilian subtropical region). We examined the relationships between environmental variations in lotic ecosystems with the seasonal dynamics of macroalgae communities at different spatial scales: drainage basin of two rivers (Rio das Pedras and Rio Marrecas), shading (open and shaded stream segments), mesohabitat (riffles and pools), and microhabitats. Data collections were made on a monthly basis between January and December/2007. A total of 16 taxa were encountered (13 species and 3 vegetative groups). All of the biotic parameters (richness, abundance, diversity, equitability, and dominance) were found to be highly variable at all of the spatial scales evaluated. On the other hand, abiotic variables demonstrated differences only at mesohabitat (in terms of current velocity) and shaded habitat (in terms of irradiance) scales. The seasonality of the macroalgae community structure was strongly influenced by microhabitat variables (current velocity, substrate $\mathrm{H}^{\prime}$, and irradiance), demonstrating their importance over time and at different scales. Regional variables (temperature, oxygen saturation, specific conductance, $\mathrm{pH}$, and turbidity) were found to have little influence on the temporal dynamics of the macroalgae communities evaluated.
\end{abstract}

Key words - heterogeneity, macroalgae, seasonal variations, stream

\section{INTRODUCTION}

In addition to the influence of spatial heterogeneity on abundance and species richness of aquatic organisms, river and stream habitats are subject to temporal variations (especially disturbance regimes) that generally have negative effects on biotic communities (Taniguchi \& Tokeshi 2004). Algal abundance can fluctuate considerably due to seasonal changes in the physical environment or because of losses due to disturbances, among other factors. Consequently, differences in algal cover may vary considerably among different substrate types over time, even though the substrate itself remains the same during the period under consideration (Downes et al. 2000).

Studies seeking to understand influence of habitat heterogeneity on the distributions of communities of aquatic organisms have only rarely taken timescales into consideration, and have almost exclusively examined communities of aquatic macro-invertebrates (e.g., Taniguchi \& Tokeshi 2004, Subramanian \&

1. Universidade Estadual do Paraná, Departamento de Biologia, Campus de União da Vitória, Praça Cel. Amazonas, Caixa Postal 291, 84600-000 União da Vitória, PR, Brazil.

2. Universidade Estadual Paulista, Departamento de Ciências Biológicas, Av. Dom Antônio, 2100, 19806-900 Assis, SP, Brazil.

3. Universidade Federal da Integração Latino-Americana, Av. Tancredo Neves, 6731, Parque Tecnológico Itaipu, 85867-970 Foz do Iguaçu, PR, Brazil.

4. Corresponding author: rogeriokrupek@yahoo.com.br
Sivaramakrishnam 2005). No published studies of this type have investigated macroalgae communities in lotic environments.

In other hand, environmental variables that appear to be driving temporal fluctuations in macroalgae communities in lotic environments (Necchi Júnior \& Pascoaloto 1993) include: water temperature (Sheath \& Burkholder 1985, Entwisle 1990, Sheath \& Hambrook 1990), irradiance (Steinman \& McIntire 1986, Steinman et al. 1989, DeNicola et al. 1992), current velocity (Reiter \& Carson 1986, Necchi Júnior et al. 1991), specific condutance (Biggs 1990, Sheath \& Cole 1992, Necchi Júnior et al. 1994, 1995), substrate type (Biggs 1990, Gordon et al. 1992), and pH (Sheath \& Burkholder 1985, Sheath \& Cole 1992). These papers focused largely on water quality, climatic conditions, and global characteristics of the habitat, and most identified essentially regional characters (e.g., $\mathrm{pH}$, water temperature, conductivity) as the principal factors responsible for structuring lotic macroalgal communities and their seasonal variations.

In spite of these suppositions, there have been no studies of macroalgae communities in lotic environments directly focusing on the influence of habitat heterogeneity at different temporal scales. The initial hypothesis of the present work was therefore that seasonal variations within the habitat cause distinct effects on abundance and species richness of stream macroalgal communities when analyzed at different spatial scales (basin, shading, mesohabitat and microhabitat). 


\section{MATERIAL AND METHODS}

The Pedras river $\left(25^{\circ} 13^{\prime}-25^{\circ} 26^{\prime} \mathrm{S}\right.$ and $51^{\circ} 13^{\prime}-51^{\circ} 28^{\prime} \mathrm{W}$; covering $\left.330 \mathrm{~km}^{2}\right)$ and Marrecas river $\left(25^{\circ} 54^{\prime}-26^{\circ} 21^{\prime} \mathrm{S}\right.$ and $52^{\circ} 54^{\prime}-53^{\circ} 17^{\prime} \mathrm{W}$; covering $765 \mathrm{~km}^{2}$ ) hydrological basins are located in the central-southern region of Paraná State in southern Brazil. Sampling of the macroalgae communities and measurements of the environmental variables were undertaken on a monthly basis during the period between January and December/2007 in selected streams in each drainage basin (figure 1).

Two areas were chosen in each basins, one with heavy gallery forest vegetation that shaded the stream, and the other without significant vegetation cover (open): i. Guabiroba
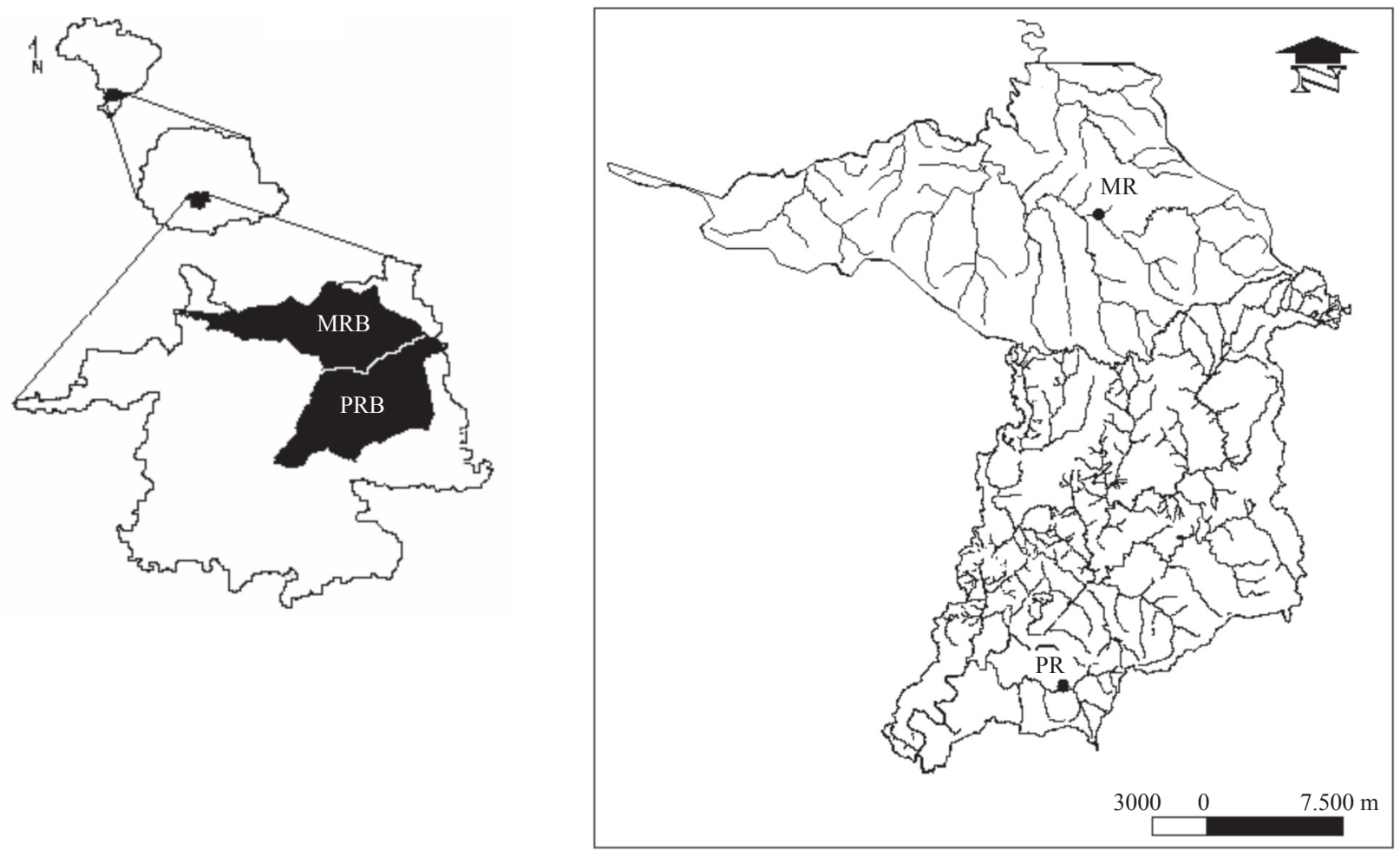

Figure 1. Details of the two drainage basins where the study was conducted indicating the sampling sites within the Pedras river (PRB) and Marrecas river (MRB) drainage basins in the central-southern region of Paraná State, Brazil, during the period between January and December/2007.

River: a second-order river located in the downstream portion of the Pedras river basin $\left(25^{\circ} 24^{\prime} \mathrm{S}-51^{\circ} 22^{\prime} \mathrm{W}\right)$, approximately $3.7 \mathrm{~m}$ wide. Two sampling sites were established, one open and one shaded, separated by $100 \mathrm{~m}$; ii. Lageadinho River: a third-order river located in the downstream portion of the Marrecas river basin $\left(25^{\circ} 11^{\prime} \mathrm{S}-51^{\circ} 21^{\prime} \mathrm{W}\right)$, approximately $2.2 \mathrm{~m}$ wide. Two sampling sites were established, one open and one shaded, separated by $200 \mathrm{~m}$.

The following spatial scales were evaluated: 1 . Drainage Basin scale (the Pedras river and Marrecas river basins); 2. Shading scale (open and shaded stream segments); 3. Mesohabitat scales (pools, with current velocity between 0 and $11.8 \mathrm{~cm} \mathrm{~s}^{-1}$; and riffles, with current velocity $>19.4 \mathrm{~cm} \mathrm{~s}^{-1}$ ); 4. Microhabitat scales (sampling units with predefined circular areas, $0.05 \mathrm{~m}^{2}$ ) in which both biotic (abundance and species richness) and environmental (luminosity, current velocity, depth, and substrate type) variables were, in fact, measured.
The stream segments examined were from 10 to $20 \mathrm{~m}$ long, and the quadrat technique was employed (Necchi Júnior et al. 1995). In each sampling unit (microhabitat scale) we observed and recorded the presence/absence of each macroalgal species and visually estimated their respective abundances in terms of percentage cover. The fieldwork and observations were made by a view-box, and specimens representative of each species were collected for subsequent laboratory analyses, following the procedures described by Necchi Júnior \& Pascoalto (1993).

The mesohabitat scales were established in pool and riffle stream regions with evident macroalgal populations. Whenever possible, 20 sampling units were established in each stream (10 sites each for the pool and riffle mesohabitats). Equal numbers of sites without macroalgae (controls) were randomly sampled to compare their microhabitat characteristics.

The current velocities and irradiance were measured at each sampling site as close to substrate level as possible 
(using a SWOFFER 2100 digital current meter and a Li-Cor 189 digital quantum radiometer/photometer with a Li-193S spherical quantum sensor respectively). The water depth was defined as the average distance between the sampling units and the water surface. The identifications of the different types of substrates were based on their size classes, as proposed by Gordon et al. (1992). Two measures of substrate heterogeneity were considered: i. substrate richness, and; ii. substrate diversity, derived from the Shannon-Wiener diversity index, utilizing the numbers of types of substrates and their proportional percentage coverage.

The following environmental variables were used to characterize each of the sampling site: water temperature, turbidity, specific conductivity, $\mathrm{pH}$, and dissolved oxygen. All of these variables were measured in the field using a HORIBA U-10 multi-parameter meter.

The materials collected in the field were preserved in $4 \%$ formaldehyde and transported to the laboratory where they were examined using a Carl Zeiss - Jenamed 2 binocular microscope fitted with an ocular micrometer. Ten measurements were taken of each algal structure analyzed. The macroalgae were identified to the species (or infraspecific) level whenever possible.

The following variables of macroalgae community structure were analyzed in each of the streams and in each sampling unit: 1. Taxa richness (numbers of taxa per sample); 2. Macroalgae abundance (percentage coverage in each sample); 3. The Shannon-Wiener diversity index: $H^{\prime}=\Sigma$ (pi) (log pi), where pi = percentage coverage of species $\mathrm{i}$ at that sample; 4. The Simpson dominance Index: $\mathrm{C}=\mathrm{a}\left(\mathrm{X}_{\mathrm{i}} / \mathrm{X}_{\mathrm{o}}\right)^{2}$ where $\mathrm{X}_{\mathrm{i}}=$ percent cover of each species in the sampling unit, and $\mathrm{X}_{\mathrm{o}}=$ total macroalgae species abundance in the sampling unit; 5. Equitability: $\mathrm{J}=\mathrm{H}^{\prime} / \mathrm{H}_{\max }$, where $\mathrm{H}^{\prime}=$ the ShannonWiener index and $\mathrm{H}_{\max }=\log \mathrm{S}$, where $\mathrm{S}=$ is the number of species sampled.

The following statistical analyses were applied to the sample data: a) Factorial Analysis of Variance (ANOVA type 3), to analyze possible variations in each of the biotic parameters at the different spatial scales (drainage basin, shading, mesohabitat) during the sampling period; b) Factorial Analysis of Variance (ANOVA - type 3), to analyze possible variations in each of the microhabitat variables (depth, current velocity, irradiance, substrate richness and diversity) during the sampling period; c) the Student $t$ Test, to compare the sampling units in terms of the presence of algae ("with algae") and the controls ("without algae") to determine possible differences in the micro-environmental characteristics at each of the spatial scales evaluated; d) Multiple Linear Regression Analysis, to evaluate the influences of all of the independent micro-environmental variables on all of the dependent biotic parameters; e) Canonic Correspondence Analysis (CCA) to identify possible influences of regional (or global) variables on the distributions of the macroalgal communities.

\section{RESULTS}

A total of sixteen taxa (13 species and three vegetative groups) were recorded in the streams in the two drainage basin studied during the period from January to December/2007 (table 1).

Table 1. Macroalgae species encountered in different mesohabitats $(\mathrm{P}=$ pools; $\mathrm{R}=$ riffles $)$ of streams $(\mathrm{O}=$ open; $\mathrm{S}=$ shaded $)$ within the drainage basins of the Pedras river (PRB) and Marrecas river (MRB), located in the central-southern region of Paraná State, Brazil, during the period between January and December/2007.

\begin{tabular}{|c|c|c|c|c|c|c|c|c|}
\hline \multirow{3}{*}{ Species } & \multicolumn{4}{|c|}{ PRB } & \multicolumn{4}{|c|}{ MRB } \\
\hline & \multicolumn{2}{|c|}{$\mathrm{O}$} & \multicolumn{2}{|c|}{$\mathrm{S}$} & \multicolumn{2}{|c|}{$\mathrm{O}$} & \multicolumn{2}{|c|}{$\mathrm{S}$} \\
\hline & $\mathrm{P}$ & $\mathrm{R}$ & $\mathrm{P}$ & $\mathrm{R}$ & $\mathrm{P}$ & $\mathrm{R}$ & $\mathrm{P}$ & $\mathrm{R}$ \\
\hline \multicolumn{9}{|l|}{ Cyanobacteria } \\
\hline Geitlerinema splendidum (Gomont) Anagnostidis & & & $\mathrm{X}$ & & & & & \\
\hline Microcoleus subtorulosus Gomont & & & $\mathrm{X}$ & $\mathrm{X}$ & & & & $\mathrm{X}$ \\
\hline Phormidium aerugineo-caeruleum (Gomont) Anagnostidis \& Komárek & $\mathrm{X}$ & $\mathrm{X}$ & $\mathrm{X}$ & $\mathrm{X}$ & $X$ & & & $\mathrm{X}$ \\
\hline Phormidium retzii Gomont & $\mathrm{X}$ & $\mathrm{X}$ & $\mathrm{X}$ & $\mathrm{X}$ & $\mathrm{X}$ & & & $\mathrm{X}$ \\
\hline Phormidium schroederi (Borge) Anagnostidis \& Komárek & $\mathrm{X}$ & & $\mathrm{X}$ & & & & & \\
\hline Tolypothrix distorta var. penicillata (Thuret) Lemmermann & $\mathrm{X}$ & $\mathrm{X}$ & & $\mathrm{X}$ & $\mathrm{X}$ & $\mathrm{X}$ & $\mathrm{X}$ & $\mathrm{X}$ \\
\hline \multicolumn{9}{|l|}{ Chlorophyta } \\
\hline Ecbalocystis pulvinata Bohlin var. pulvinata & & & & & $X$ & $X$ & & $\mathrm{X}$ \\
\hline Mougeotia sp. & $\mathrm{X}$ & & & $\mathrm{X}$ & $\mathrm{X}$ & & $\mathrm{X}$ & \\
\hline Spirogyra sp. & & & & & $\mathrm{X}$ & & & \\
\hline Stigeoclonium helveticum Vischer & $\mathrm{X}$ & $\mathrm{X}$ & $\mathrm{X}$ & $\mathrm{X}$ & & & & \\
\hline Tetraspora lubrica (Roth) C.Agardh & & $\mathrm{X}$ & $\mathrm{X}$ & $\mathrm{X}$ & & & & \\
\hline Tetraspora gelatinosa (Vaucher) Desvaux & $\mathrm{X}$ & & & & & & & \\
\hline
\end{tabular}


continuation

\begin{tabular}{|c|c|c|c|c|c|c|c|c|}
\hline \multirow{3}{*}{ Species } & \multicolumn{4}{|c|}{ PRB } & \multicolumn{4}{|c|}{ MRB } \\
\hline & \multicolumn{2}{|c|}{$\mathrm{O}$} & \multicolumn{2}{|c|}{$\mathrm{S}$} & \multicolumn{2}{|c|}{$\mathrm{O}$} & \multicolumn{2}{|c|}{$\mathrm{S}$} \\
\hline & $\mathrm{P}$ & $\mathrm{R}$ & $\mathrm{P}$ & $\mathrm{R}$ & $\mathrm{P}$ & $\mathrm{R}$ & $\mathrm{P}$ & $\mathrm{R}$ \\
\hline Heterokontophyta & & & & & & & & \\
\hline Vaucheria geminata (Vaucher) De Candolle & $\mathrm{X}$ & & & & & & & \\
\hline Rhodophyta & & & & & & & & \\
\hline Batrachospermum helminthosum Bory & & & & & & & $\mathrm{X}$ & \\
\hline Batrachospermum puiggarianum Grunow in Wit. et Nordstedt & & $\mathrm{X}$ & & & & & & \\
\hline $\begin{array}{l}\text { Kumanoa abili (Reis) Entwisle, Vis, Chiasson, Necchi Júnior \& } \\
\text { Sherwood }\end{array}$ & $\mathrm{X}$ & $\mathrm{X}$ & $\mathrm{X}$ & $\mathrm{X}$ & & & & \\
\hline
\end{tabular}

Each of the variables related to the macroalgae community structures showed unique types of variations during the seasonal periods studied (table 2), but generally only small variations at the different spatial scales examined (except for abundance, which demonstrated wide variations at different scales) were observed.

All of the biotic variables analyzed demonstrated different types of temporal variations within the spatial

Table 2. Average values and standard deviations of the biotic variables (richness, abundance, diversity indices = H'; dominance $=\mathrm{C}$; equitability $=\mathrm{J}$ ) measured at different spatial scales within the drainage basins of the Pedras $(\mathrm{PRB})$ and Marrecas $(\mathrm{MRB})$ rivers, located in the central-southern region of Paraná State, Brazil, during the period between January and December/2007. $(\mathrm{PRB}=$ Rio das Pedras river basin; $\mathrm{MRB}=$ Rio Marrecas river basin).

\begin{tabular}{|c|c|c|c|c|c|c|c|}
\hline & Scale & & Richness & Abundance & $\mathrm{H}^{\prime}$ & $\mathrm{C}$ & $\mathrm{J}$ \\
\hline & \multirow[t]{3}{*}{ Basins } & General & $1.61 \pm 0.85$ & $10.9 \pm 13.5$ & $0.08 \pm 0.12$ & $0.84 \pm 0.24$ & $0.21 \pm 0.33$ \\
\hline & & RDP & $1.95 \pm 0.94$ & $9.51 \pm 11.4$ & $0.12 \pm 0.14$ & $0.78 \pm 0.24$ & $0.31 \pm 0.37$ \\
\hline & & $\mathrm{RM}$ & $1.27 \pm 0.57$ & $12.3 \pm 15.4$ & $0.03 \pm 0.08$ & $0.90 \pm 0.23$ & $0.11 \pm 0.26$ \\
\hline & \multirow[t]{3}{*}{ Open } & General & $1.77 \pm 0.95$ & $10.9 \pm 13.7$ & $0.10 \pm 0.14$ & $0.78 \pm 0.27$ & $0.27 \pm 0.35$ \\
\hline & & RDP & $2.25 \pm 0.98$ & $12.6 \pm 13.4$ & $0.16 \pm 0.16$ & $0.68 \pm 0.27$ & $0.40 \pm 0.39$ \\
\hline & & $\mathrm{RM}$ & $1.29 \pm 0.62$ & $9.35 \pm 14.0$ & $0.04 \pm 0.08$ & $0.88+0.23$ & $0.14 \pm 0.27$ \\
\hline & \multirow[t]{3}{*}{ Shaded } & General & $1.45 \pm 0.71$ & $10.8 \pm 13.5$ & $0.05 \pm 0.10$ & $0.89 \pm 0.20$ & $0.16 \pm 0.30$ \\
\hline & & RDP & $1.66 \pm 0.81$ & $6.41 \pm 8.09$ & $0.08 \pm 0.11$ & $0.87 \pm 0.17$ & $0.23 \pm 0.33$ \\
\hline & & $\mathrm{RM}$ & $1.25 \pm 0.53$ & $15.2 \pm 16.4$ & $0.02 \pm 0.07$ & $0.91 \pm 0.23$ & $0.08 \pm 0.25$ \\
\hline & \multirow[t]{3}{*}{ Basins } & General & $1.29 \pm 0.74$ & $2.67 \pm 4.73$ & $0.05 \pm 0.11$ & $0.84 \pm 0.28$ & $0.16 \pm 0.31$ \\
\hline \multirow{8}{*}{$\begin{array}{l}\overrightarrow{0} \\
0 \\
2\end{array}$} & & Open & $1.45 \pm 0.88$ & $2.51 \pm 3.20$ & $0.09 \pm 0.13$ & $0.77 \pm 0.31$ & $0.25 \pm 0.37$ \\
\hline & & Shaded & $1.12 \pm 0.53$ & $2.84 \pm 5.95$ & $0.02 \pm 0.07$ & $0.92 \pm 0.22$ & $0.07 \pm 0.23$ \\
\hline & \multirow[t]{3}{*}{ PRB } & General & $1.50 \pm 0.82$ & $4.37 \pm 6.11$ & $0.10 \pm 0.13$ & $0.79 \pm 0.26$ & $0.30 \pm 0.39$ \\
\hline & & Open & $1.83 \pm 0.93$ & $3.60 \pm 3.86$ & $0.16 \pm 0.14$ & $0.66 \pm 0.30$ & $0.45 \pm 0.41$ \\
\hline & & Shaded & $1.33 \pm 0.65$ & $5.13 \pm 7.87$ & $0.04 \pm 0.09$ & $0.93 \pm 0.13$ & $0.15 \pm 0.31$ \\
\hline & \multirow[t]{3}{*}{ MRB } & General & $1.0 \pm 0.51$ & $0.98 \pm 1.55$ & $0.01 \pm 0.04$ & $0.90 \pm 0.28$ & $0.02 \pm 0.10$ \\
\hline & & Open & $1.08 \pm 0.66$ & $1.42 \pm 1.99$ & $0.02 \pm 0.06$ & $0.88 \pm 0.30$ & $0.04 \pm 0.14$ \\
\hline & & Shaded & $0.91 \pm 0.28$ & $0.55 \pm 0.88$ & $0.0 \pm 0.0$ & $0.91 \pm 0.28$ & $0.0 \pm 0.0$ \\
\hline \multirow{9}{*}{ 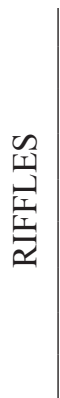 } & \multirow[t]{3}{*}{ Basins } & General & $1.93 \pm 0.83$ & $19,1 \pm 14.5$ & $0.10 \pm 0.13$ & $0.83 \pm 0.21$ & $0.27 \pm 0.34$ \\
\hline & & Open & $2.08 \pm 0.92$ & $19,4 \pm 14.9$ & $0.12 \pm 0.14$ & $0.79 \pm 0.23$ & $0.29 \pm 0.35$ \\
\hline & & Shaded & $1.79 \pm 0.72$ & $18.8 \pm 14.4$ & $0.09 \pm 0.12$ & $0.86 \pm 0.19$ & $0.24 \pm 0.34$ \\
\hline & \multirow[t]{3}{*}{ PRB } & General & $2.33+0.91$ & $14.6+13.2$ & $0.14+0.15$ & $0.76+0.23$ & $0.33+0.35$ \\
\hline & & Open & $2.66 \pm 0.88$ & $21.6 \pm 13.7$ & $0.16 \pm 0.17$ & $0.70 \pm 0.25$ & $0.35 \pm 0.37$ \\
\hline & & Shaded & $2.0 \pm 0.85$ & $7.69 \pm 8.45$ & $0.12 \pm 0.12$ & $0.82 \pm 0.20$ & $0.31 \pm 0.34$ \\
\hline & \multirow[t]{3}{*}{ MRB } & General & $1.54 \pm 0.50$ & $23.6 \pm 14.6$ & $0.06 \pm 0.10$ & $0.90 \pm 0.17$ & $0.20 \pm 0.33$ \\
\hline & & Open & $1.50 \pm 0.52$ & $17.2 \pm 16.4$ & $0.07 \pm 0.10$ & $0.88 \pm 0.17$ & $0.24 \pm 0.33$ \\
\hline & & Shaded & $1.58 \pm 0.51$ & $30.0 \pm 9.62$ & $0.05 \pm 0.10$ & $0.91 \pm 0.17$ & $0.17 \pm 0.34$ \\
\hline
\end{tabular}


scales evaluated. Species richness and diversity indices varied significantly at all spatial scales, while species abundance and equitability demonstrated significant variations only at the mesohabitat and drainage basin scales, respectively (table 3). Dominance showed significant seasonal variations in terms of the drainage basin and shade conditions.

Different from observed for the biotic variables, environmental variables demonstrated only low temporal variations at the spatial scales evaluated. Only current velocity showed significant differences at the mesohabitat scale $(\mathrm{F}=279.69 ; P<0.001)$, and irradiance at shading $(\mathrm{F}=85.90 ; P<0.001)$ and mesohabitat $(\mathrm{F}=11.96$; $P<0.001)$ scales. Similarly, there were little significant differences between the sampling sites "with algae" and "without algae" in terms of all of the microhabitat variables analyzed. Significant differences were found in the riffles mesohabitat for depth $(t=-4.758 ; P<0.001)$, substrate richness $(t=-3.822 ; P<0.001)$, and substrate $\mathrm{H}^{\prime}(t=-2.028 ; \mathrm{p}<0.05)$.

The Multiple Linear Regression Analysis revealed numerous influences of microhabitat variables at different scales on all of the biotic variables evaluated during the different seasons (table 4). Richness was significantly related

Table 3. Summary of the results of ANOVA, demonstrating temporal differences in macroalgae community structures at the different spatial scales as evaluated during the period between January and December/2007 in streams in the central-southern region of Paraná State, Brazil.

\begin{tabular}{lcc}
\hline Spatial scale & F & $P$ \\
\hline Species richnesses & & \\
Drainage basin & 23.35 & 0.000 \\
Open/Shaded & 4.82 & 0.030 \\
Pool/Riffles & 20.60 & 0.000 \\
Abundance & & \\
Drainage basin & 2.13 & 0.147 \\
Open/Shaded & 0.005 & 0.942 \\
Pool/Riffles & 73.97 & 0.000 \\
Richness, abundance, & & \\
diversity indices (H') & & \\
Drainage basin & 14.80 & 0.000 \\
Open/Shaded & 4.27 & 0.041 \\
Pool/Riffles & 4.13 & 0.045 \\
Dominance (C) & & \\
Drainage basin & 6.09 & 0.015 \\
Open/Shaded & 5.35 & 0.023 \\
Pool/Riffles & 0.11 & 0.731 \\
Equitability (J) & & \\
Drainage basin & 10.05 & 0.002 \\
Open/Shaded & 3.10 & 0.081 \\
Pool/Riffles & 2.81 & 0.096 \\
\hline
\end{tabular}

to abiotic variables at all scales, while abundance was not significantly related only to riffle mesohabitat (table 4). The Diversity and Dominance indices indicated some significant relationships at different spatial scales, while Equitability showed significant relationships with microhabitat variables only to riffle mesohabitat (table 4).

Canonic Correspondence Analyses (CCA; figure 2) performed with all of the regional variables showed low explicability (13.1\%); with significant correlations were only for the second axis.
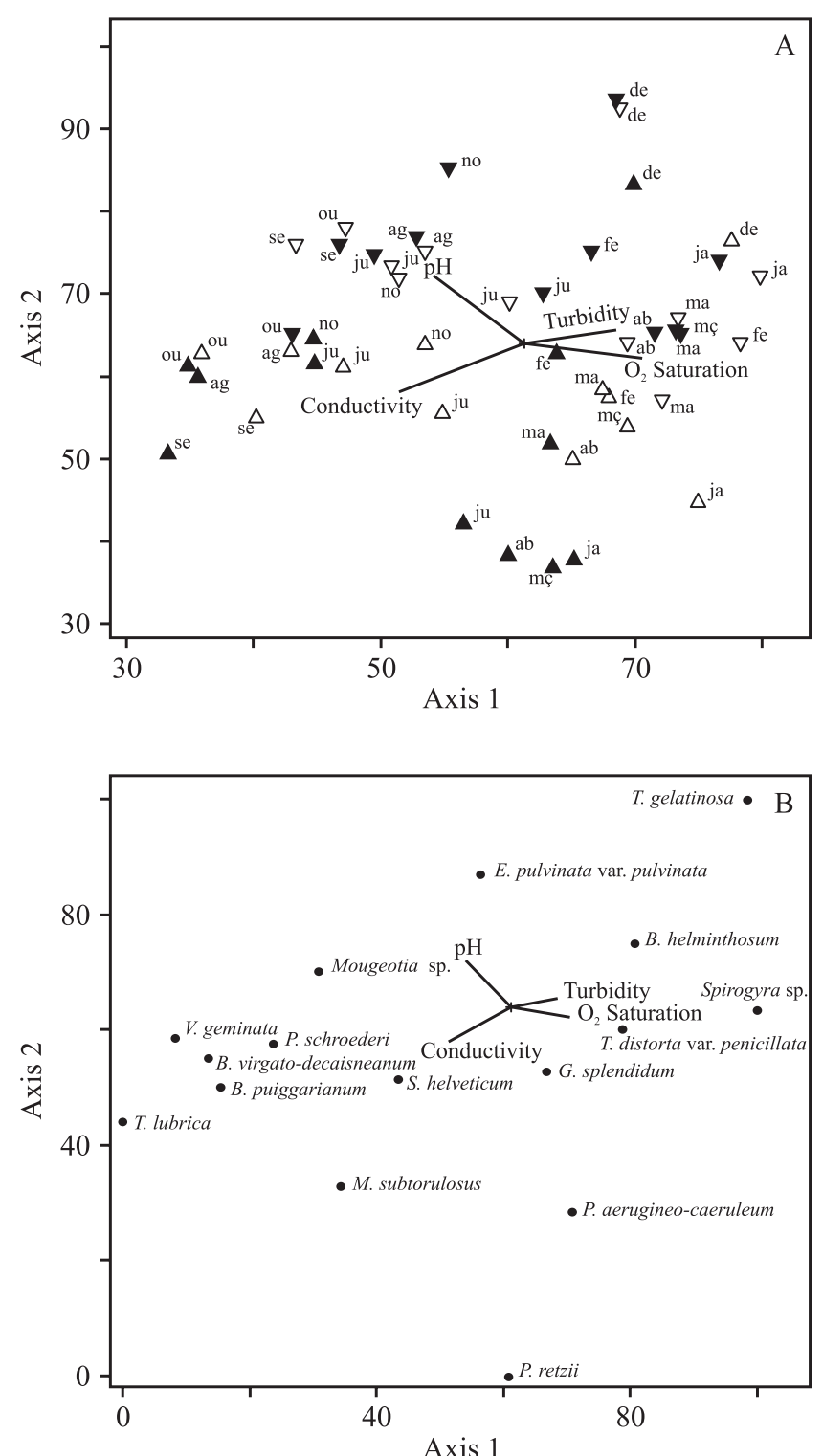

Figure 2. Results of the Canonic Correspondence Analysis (CCA) for the four stream segments sample during the study period (A) and for the species encountered (B). The vectors indicate the directions of the influences of the variables. ( $\Delta=$ The Pedras river basin; open segment; $\Delta=$ shaded segment; $\nabla=$ Marrecas river basin; open segment; $\mathbf{\nabla}=$ shaded segment). 
Table 4. Summary of the Multiple Regression Analysis demonstrating the influences of the micro-environmental variables examined on each of the structural variables of the macroalgal communities at different spatial scales within the drainage basins of the Pedras (PRB) and Marrecas (MRB) rivers, located in the central-southern region of Paraná State, Brazil, during the period between January and December/2007. $\left(\mathrm{R}^{2}=\right.$ determination coefficient; $\mathrm{F}=$ statistic significance; $P=$ significance level).

\begin{tabular}{|c|c|c|c|c|}
\hline Variable & $\mathrm{R}^{2}$ & $\mathrm{~F}$ & $P$ & Most influential variables \\
\hline \multicolumn{5}{|l|}{ Richness } \\
\hline Drainage basin & 29.4 & 7.50 & 0.000 & $\begin{array}{l}\text { Substrate H': } 17.2 \\
\text { Depth: } 1.56\end{array}$ \\
\hline Open environment & 40.1 & 5.62 & 0.000 & $\begin{array}{l}\text { Substrate H': } 37.4 \\
\text { Current velocity: }-23.0 \\
\text { Depth: } 2.54\end{array}$ \\
\hline Shaded environment & 37.6 & 5.08 & 0.000 & Depth: 1.08 \\
\hline Pools mesohabitat & 29.5 & 3.36 & 0.012 & $\begin{array}{l}\text { Substrate H': } 0.871 \\
\text { Depth: } 0.338\end{array}$ \\
\hline Riffles mesohabitat & 34.5 & 4.42 & 0.002 & Depth: 0.401 \\
\hline \multicolumn{5}{|l|}{ Abundance } \\
\hline Drainage basin & 38.4 & 11.2 & 0.000 & $\begin{array}{l}\text { Substrate H': }-23.0 \\
\text { Current velocity: } 22.5 \\
\text { Irradiance: } 0.189\end{array}$ \\
\hline Open environment & 60.8 & 13.0 & 0.000 & $\begin{array}{l}\text { Substrate H': }-20.0 \\
\text { Current velocity: } 17,5 \\
\text { Irradiance: } 0.400\end{array}$ \\
\hline Shaded environment & 29.9 & 3.59 & 0.008 & Current velocity: 16.9 \\
\hline Pools mesohabitat & 18.7 & 1.84 & 0.125 & \\
\hline Riffles mesohabitat & 29.6 & 3.54 & 0.009 & $\begin{array}{l}\text { Current velocity: } 0.360 \\
\text { Irradiance: } 0.335\end{array}$ \\
\hline \multicolumn{5}{|c|}{$\begin{array}{l}\text { Richness, abundance, diversity } \\
\text { indices (H') }\end{array}$} \\
\hline Drainage basin & 11.4 & 2.31 & 0.049 & $\begin{array}{l}\text { Substrate H': } 21.6 \\
\text { Current velocity: }-14.0 \\
\text { Depth: } 0.979\end{array}$ \\
\hline Open environment & 14.3 & 1.40 & 0.240 & \\
\hline Shaded environment & 29.8 & 3.57 & 0.008 & Irradiance: 0.395 \\
\hline Pools mesohabitat & 23.6 & 2.48 & 0.047 & $\begin{array}{l}\text { Substrate H': } 0.593 \\
\text { Depth: } 0.330\end{array}$ \\
\hline Riffles mesohabitat & 17.6 & 1.80 & 0.133 & \\
\hline \multicolumn{5}{|l|}{ Dominance $(\mathrm{C})$} \\
\hline Drainage basin & 30.8 & 8.01 & 0.000 & Current velocity $=4.84$ \\
\hline Open environment & 33.4 & 4.21 & 0.003 & Substrate H': 9.10 \\
\hline Shaded environment & 56.3 & 10.83 & 0.000 & Irradiance: -0.270 \\
\hline Pools mesohabitat & 22.1 & 2.27 & 0.065 & \\
\hline Riffles mesohabitat & 14.9 & 1.47 & 0.216 & \\
\hline \multicolumn{5}{|l|}{ Equitability (J) } \\
\hline Drainage basin & 10.7 & 2.16 & 0.065 & \\
\hline Open environment & 15.5 & 1.55 & 0.194 & \\
\hline Shaded environment & 20.1 & 2.12 & 0.081 & \\
\hline Pools mesohabitat & 25.6 & 2.75 & 0.031 & $\begin{array}{l}\text { Substrate H': } 0.541 \\
\text { Irradiance: } 0.370\end{array}$ \\
\hline Riffles mesohabitat & 14.3 & 1.41 & 0.239 & \\
\hline
\end{tabular}




\section{DISCUSSION}

In considering the stream macroalgal community structure, the present study indicated that differences in the biotic variables were much more evident at temporal rather than spatial scales.

The wide variations in the biotic parameters evaluated in the present study demonstrated the strong influence of temporal conditions on spatial characteristics and, consequently, on the structures of the macroalgal communities. Among the parameters evaluated, species richness and diversity index showed significant seasonal differences at all spatial scales, indicating that these variables were extremely sensitive to temporal scale variations - especially considering that very few environmental variables demonstrated significant differences at those scales. Species abundance, in turn, showed significant differences only at the mesohabitat scale. The absence of significant differences in the percentage coverage of macroalgae (differing from that observed in terms of species richness) is probably due to particular characteristics of that group, as a number of studies have reported macroalgae communities with generally low abundances (Branco \& Necchi Júnior 1996, Necchi Júnior et al. 2000, Borges \& Necchi Júnior 2006, Krupek et al. 2007, Branco et al. 2009). This situation may be responsible for the similarities of abundance values observed at different scales.

The high dominance and low equitability values observed were perfectly coherent in terms of the group of organisms studied. Macroalgae communities commonly show one or just a few dominant species (Borges \& Necchi Júnior 2006). Seasonally, the predominance of one species is probably due to some unique characteristic(s) of that taxon that makes it more tolerant to adverse and highly changeable environmental conditions (Stevenson 1997). These tolerant species are capable of supporting tolerant of environmental changes, such as significant changes in water flow, and proliferate more rapidly and attain greater abundances (Borges \& Necchi Júnior 2006).

Few significant differences were observed in local environmental variables at different temporal scales. The differences in irradiance noted at the shading scales, and in current velocity at the mesohabitat scale would appear to be the principal factors responsible for the observed variations in the community structures of macroalgae.

Fluctuations in current velocity may have important influences on fixed algae communities. These effects may be positive (such as those related to nutrient delivery and greater oxygenation of the water), or negative (due to the abrasive mechanical effects of water flow) (Gordon et al. 1992, Branco \& Necchi Júnior 1997, Stevenson 1997), and the differences observed between the mesohabitats confirmed this statement. Similarly, irradiance can be determinant in terms of the development of different species of macroalgae, affecting both abundance and species richness (Sheath \& Burkholder 1985, Steinman and \& McIntire 1987).

Microhabitat variables provoked different influences on the seasonality of all of the biotic variables of the macroalgae communities at the different spatial scales evaluated showing that the stream macroalgal community structure are intimately related to microhabitat variables over time and at all spatial scales. These results suggested that seasonality of these organisms is strongly influenced by spatial heterogeneity produced over time on the characteristics of the microhabitat. The variables that most influenced stream macroalgae seasonality were current velocity, water depth, and substrate H' and, to a lesser degree, irradiance. The smaller influence of irradiance may be due to factors related to the data collection process. As irradiance measurements depend directly on climatic conditions, - which can vary widely over time (changing in cloud cover within a single day, for example) - isolated measures may contain errors and not faithfully reflect the true influence of this parameter. As such, water depth can be considered an indirect measure of the amount of light reaching the river bottom (Krupek et al. 2008).

We observed an interesting relationship between abundance and species richness and substrate H'. Species richness was positively influenced, and abundance negatively influenced, by substrate diversity in the sampling units during the temporal sampling periods. It is widely accepted that spatial heterogeneity (as represented by river bottom substrate diversity) has a direct positive influence on species richness (Dudley et al. 1986, Douglas \& Lake 1994, Robson \& Barmuta 1998, Taniguchi \& Tokeshi 2004, Borges \& Necchi Júnior 2006, Murdock \& Dodds 2007). So much greater the diversity of substrates present in a given location, the greater the diversity of niches and resources available to different species of macroalgae. In terms of abundance, however, this inverse relationship between substrate diversity and abundance may be closely related to the substrate particles sizes. Higher substrate diversity sampling units will necessarily mean the presence of smaller substrate particles, and as macroalgae usually demonstrate better development on larger particle substrates (McConnel \& Sigler 1959, Tett et al. 1978, Uehlinger 1991, Cazaubon 1995, Cattaneo et al. 1997, Downes et al. 2003), diminishing substrate size will consequently diminish macroalgae abundance. Large substrate particles are more stable, experience less abrasive wear from water currents, and thus allow 
the development of higher abundance of the few algal species tolerant of seasonal variations in water flow rates (Cattaneo et al. 1997).

Regional variations had little influence on seasonal patterns of macroalgae community distributions, showing that they have relatively less influence on the temporal distributions of macroalgae communities than microhabitat variables.

Acknowledgments - The authors thank CNPq for the doctoral grant awarded to RAK and for the research scholarship to CCZB (Proc. 302354/2008-5).

\section{REFERENCES}

Biggs BJF. 1990. Periphyton communities and their enviroments in New Zealand rivers. New Zealand Journal of Marine and Freshwater Reserch 24:367-386.

Borges FR, Necchi Júnior O. 2006. Patterns of spatial distribution in macroalgal communities from tropical lotic ecosystems. Brazilian Journal of Botany 29:669-680.

Branco CCZ, Krupek RA, Peres CK. 2009. Ecological distribution of stream macroalgal communities from mid-western region of Paraná State. Brazilian Archives of Biology and Technology 52:379-386.

Branco CCZ, Necchi Júnior O. 1996. Distribution of stream macroalgae in the eastern Atlantic rainforest of São Paulo State, southeastern Brazil. Hydrobiologia 333:139-150.

Branco LHZ, Necchi Júnior O. 1997. Seasonality of macroalgae in three tropical drainage basins in São Paulo State, southeastern Brazil. Archiv fur Hydrobiologie 141:75-91.

Cattaneo A, Kerimian T, Roberge M, Marty J. 1997. Periphyton distribution and abundance on substrata of different size along a gradient of stream trophy. Hydrobiology 354:101-110.

Cazaubon A, Rolland T, Loudiki M. 1995. Heterogeneity of periphyton in French Mediterranean rivers. Hydrobiologia 300/301:105-114.

DeNicola DM, Hogland KD, Roemer SC. 1992. Influence of canopy cover on spectral irradiance and periphyton assemblages in a prairie stream. Journal of North American Benthological Society 11:391-404.

Douglas M, Lake PS. 1994. Species richness of stream stones: an investigation of the mechanisms generating the species-area relationship. Oikos 69:387-396.

Downes BJ, Entwisle TJ, Reich P. 2003. Effects of flow regulation on disturbance frequencies and in-channel bryophytes and macroalgae in some upland streams. River Reserch and Applications 19:27-42.

Downes BJ, Lake PS, Schreiber ESG, Glaister A. 2000. Habitat structure, resources and diversity: the separate effects of surface roughness and macroalgae on stream invertebrates. Oecologia 123:569-581.
Dudley TL, Cooper SD, Hemphill N. 1986. Effects of macroalgae on stream invertebrate community. Journal of North American Benthological Society 5:93-106.

Entwisle TJ. 1990. Macroalgae in the upper Yarra and Watts River catchments: distribution and phenology. Australian Journal of Marine and Freshwater Reserch 41:505-522.

Gordon ND, McMahon TA, Finlaylson BL. 1992. Stream hydrology, an introduction for ecologists. John Wiley \& Sons, Chichester.

Krupek RA, Branco CCZ, Peres CK. 2008. Variação sazonal de alguns parâmetros físicos e químicos em três rios pertencentes a uma bacia de drenagem na região centrosul do Estado do Paraná, Sul do Brasil. Acta Scientiarum Biological Sciences 30:431-438.

Krupek RA, Branco CCZ, Peres CK. 2007. Distribuição ecológica das comunidades de macroalgas da bacia de drenagem do Rio das Pedras, região centro-sul do estado do Paraná, sul do Brasil. Revista Brasileira de Botânica 30:173-182.

McConnel WJ, Singler WF. 1959. Chlorophyll and productivity in a mountain river. Limnology and Oceanography 4:335-351.

Murdock JN, Dodds WK. 2007. Linking benthic algal biomass to stream substratum topography. Journal of Phycology 43:449-460.

Necchi Júnior O, Pascoaloto D. 1993. Seasonal dynamics of macroalgal communities in the Preto River basin, São Paulo, southeastern Brazil. Archiv fur Hydrobiologie 129:231-252.

Necchi Júnior O, Branco CCZ, Branco LHZ. 2000. Distribution of stream macroalgae in São Paulo State, southeastern Brazil. Algological Studies 97:43-57.

Necchi Júnior O, Dip MR, Góes RM. 1991. Macroalgae of a stream in southeastern Brazil: composition, seasonal variation and relation to physical and chemical variables. Hydrobiologia 213:241-250.

Necchi Júnior O, Branco CCZ, Simões RCG, Branco LHZ. 1995. Distribution of stream macroalgae in northwest region of São Paulo State, southeastern Brazil. Hydrobiologia 299:219-230.

Necchi Júnior O, Pascoaloto D, Branco LHZ. 1994. Distribution of macroalgae in a tropical river basin from southeastern Brazil. Archiv fur Hydrobiologie 129:459-471.

Reiter MA, Carlson RE. 1986. Current velocity in streams and the composition of benthic algal mats. Canadian Journal of Fisheries and Aquatic Sciences 43:1156-1162.

Robson BJ, Barmuta LA. 1998. The effect of two scales of habitat architecture of benthic grazing in a river. Freshwater Biology 39:207-220.

Sheath RG, Cole KM. 1992. Biogeography of stream macroalgae in North American Journal of Phycology 28:448-460.

Sheath RG, Burkholder J. 1985. Characteristics of softwater stream in Rhode Island. II: Composition and seasonal dynamics of macroalgae communities. Hydrobiologia 128:109-118. 
Sheath RG, Hambrook JA. 1990. Freshwater ecology. In Biology of red algae. (KM Cole, RG Sheath, eds.) Cambridge University Press, Cambridge, p.423-453.

Steinman AD, McIntire CD, Gregory SVL, Lamberti GA. 1989. Effects of irradiance and grazing on lotic algal assemblages. Journal of Phycology 25:478-485.

Steinman AD, McIntire CD. 1987. Effects of irradiance on the community structure and biomass of algal assemblages in laboratory streams. Canadian Journal of Fisheries and Aquatic Sciences 44:1640-1648.

Stevenson RJ. 1997. Scale-dependent determinants and consequences of benthic algal heterogeneity. Journal of North American Benthological Society 16:248-262.
Subramanian KA, Sivaramakrishnan KG. 2005. Habitat and microhabitat distribution of stream insect communities of the Western Ghats. Current Science 89:976-987.

Taniguchi H, Tokeshi M. 2004. Effects of habitat complexity on benthic assemblages in a variable environment. Freshwater Biology 49:1164-1178.

Tett P, Callegos C, Kelly MG, Hornberger GM, Cosby BJ. 1978. Relationships among substrate, flow, and benthic microalgal pigment density in the Mechums river, Virginia. Limnological Oceanographyc 23:219-237.

Uehlinger U. 1991. Spatial and temporal variability of the periphyton biomass in a prealpine river (Necker, Switzerland). Archiv fur Hydrobiology 123:219-237. 
